\title{
The protection of the mountain ecosystems of the Southern Central Andes: tensions between Aymara herding practices and conservation policies
}

\author{
Magdalena García, Manuel Prieto \& Fernanda Kalazich \\ Keywords: herding, Aymaras, traditional ecological knowledge, protected areas
}

\section{Abstract}

In the Atacama Desert highlands, Aymara communities have practised herding since pre-Hispanic times. Currently, large areas of the mountains' ecosystems are under official protection. This situation has created tensions between Aymara herding practices and official conservation policies. In this article, we document herding practices and how they have contributed to the production of these ecosystems. We also explore several conservation policies in the area and how they clash with Aymara herding. To do this, we make use of ethnography and state conservation plans. We suggest that these policies reproduce colonial dynamics, creating conflicting aims and affecting Aymara territorial rights. We conclude that traditional Aymara ecological knowledge and practices should guide the conservation of these mountain ecosystems.

\section{Profile}

Protected area

National System of

Protected Wild Areas

Mountain range

Andes, Chile

\section{Introduction}

Prevailing ideas about nature present human action as synonymous with environmental degradation (Dove \& Carpenter 2006). Nevertheless, there is widespread scientific recognition of the value of traditional ecological knowledge and practices for the production and safeguarding of nature (Posey 1985; Berkes 1999). Official conservation practices, however, tend to render local actors invisible, and - paradoxically adversely affecting the very ecosystems they aim to preserve (Fairhead \& Leach 1996). This tension is in urgent need of exploration within the mountain ecosystems of the Southern Central Andes (Eisenberg 2013; Jofré 2014; Yepez 2020), as it is highly relevant to questions of biodiversity, the livelihoods of those who inhabit these areas, and the global climate system (Yager et al. 2019). In particular, the Puna (ca. 3000-5200 $\mathrm{m}$ a.s.l.), located in the border area between Bolivia, Peru, Argentina and Chile, is one of the regions with highest endemic levels of flora and fauna worldwide (Hribljan et al. 2015). For over three millennia - since at least $2500 \mathrm{BCE}$ - herding societies have inhabited the Puna, building upon knowledge and techniques of camelid breeding, specifically llamas (Lama glama) and alpacas (Vicugna pacos), and managing their lands through diverse cultural practices such as the irrigation of Andean wetlands (known as vegas and bofedales) and transhumance (Flores Ochoa 1977; Lane \& Grant 2016; Erickson 2000; Capriles \& Tripcevich 2016). Given its ecological importance, a significant part of Aymara territory in the Chilean regions of Arica-Parinacota and Tarapacá $\left(18^{\circ}-20^{\circ} \mathrm{S}\right)$ is under both State conservation protection through the National System of Protected Wild Areas (Sistema Nacional de Areas Silvestres Protegidas del Estado (SNASPE)), and international protection by UNESCO and the RAMSAR convention (Figure 1; Table 1). All of these areas are managed by the National Forestry Corporation (Corporación Nacional Forestal, hereinafter referred to by its acronym, CONAF).

Despite their good intentions, several conservation policies implemented within the Puna Reserves have been the primary drivers of conflict, affecting Aymara herders' practice of their cultural traditions and their territorial rights. Aymara indigenous lands account for around $98 \%$ of the Lauca Biosphere Reserve's surface area (José Barraza, personal communication, 2020; Eisenberg 2013); however, like all other designated protected areas, these lands are managed by the State through CONAF. In this context, Aymara agency has been minimized and Aymaran practices looked down upon, with dialogue between policy makers and traditional owners rare. Moreover, this situation has created contradictions that threaten the sustainability of the ecosystems subjected to these policies.

In addition - and also in contradiction - to ensuring conservation in the Lauca Reserve, the State has granted mining concessions and developed water infrastructures affecting ecosystems and Aymara water security (Eisenberg 2013). This is coupled with problems related to urban migration and the subsequent depopulation of indigenous territories, leaving the latter susceptible to the radical Chilean neoliberal economic model (Eisenberg 2013). Currently, a total of 156754 people in Chile self-identify as Aymara (INE 2018); at least two-thirds live in urban areas, and the rural population is older on average, reflecting the migration of younger generations (Eisenberg 2013; González et al. 2014). Despite the fact that the Aymara maintain ties with their communities of origin (González 1997; Eisenberg 2013; González et al. 2014), their herding practices are decreasing, and many cultural management practices have diminished or disappeared. This has resulted in the high-altitude Andean wetlands becoming more vulnerable (Yager et al. 2019), and live- 


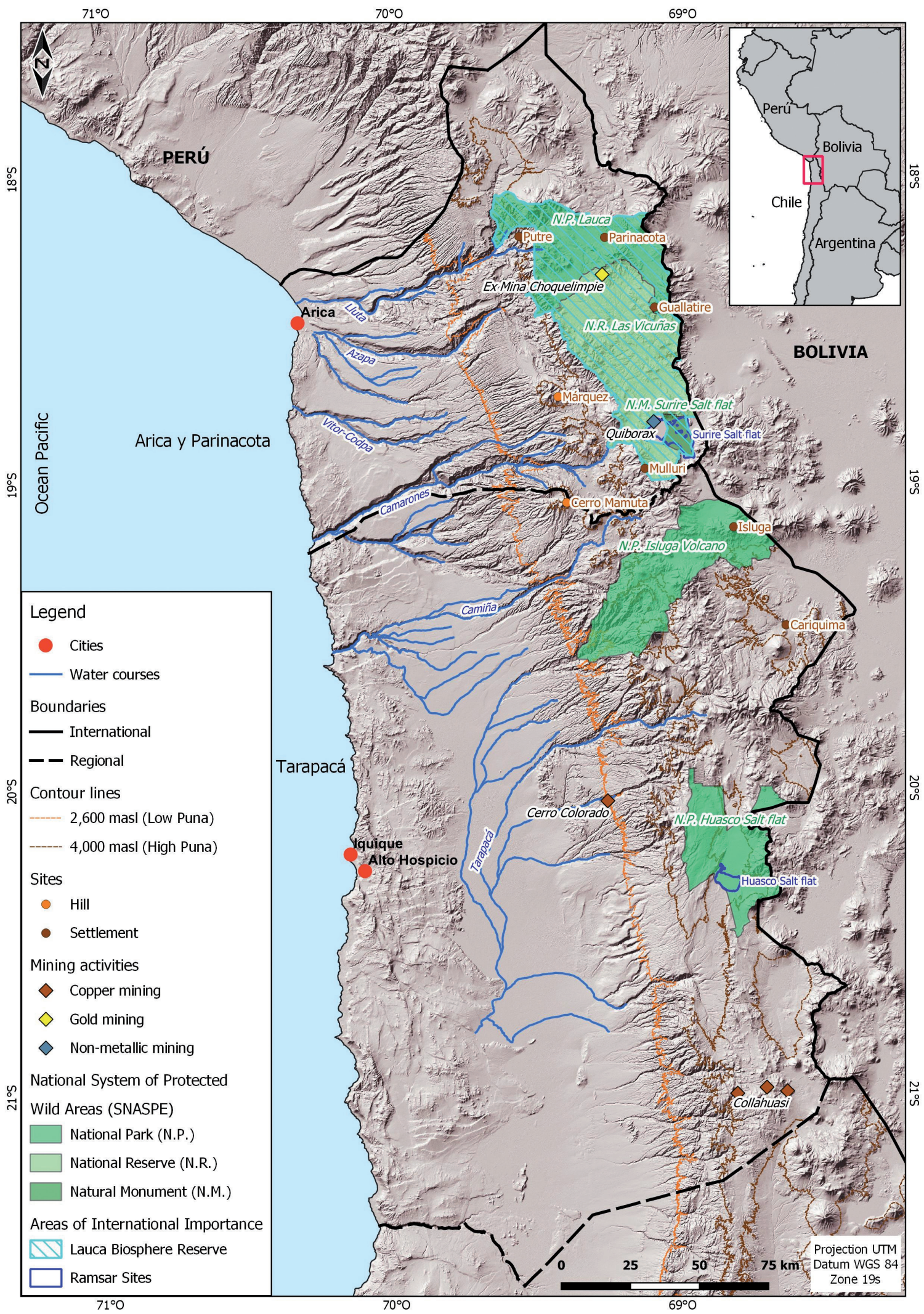

Figure 1 - Study area of Arica-Parinacota and Tarapaca regions.

stock rotation and transhumance circuits becoming more restricted (van Kessel 1992; García 2018).

The aim of this article is to draw attention to the frequently overlooked sociocultural landscape of the Puna, which is as relevant as its ecological traits for effectively securing the preservation of this ecosystem. Through the use of ethnography and participatory methodologies, we document the Aymara's traditional herding practice of the costeo - a form of transhumance - and their care and nurturing practices 
Table 1 - Protected areas in the Aymara-Chilean territory.

\begin{tabular}{|l|r|c|l|l|}
\hline SNASPE & Area (ha) & Lauca Biosphere Reserve (UNESCO) & Ramsar Site & Region \\
\hline Lauca National Park & 137833 & $\mathrm{X}$ & & Arica-Parinacota \\
\hline Las Vicuñas National Reserve & 209131 & $\mathrm{X}$ & & Arica-Parinacota \\
\hline Salar de Surire Natural Monument & 11298 & $\mathrm{X}$ & $\mathrm{X}$ & Arica-Parinacota \\
\hline Volcán Isluga National Park & 174744 & & & Tarapacá \\
\hline Salar del Huasco National Park & 9950 & & $\mathrm{X}$ & Tarapacá \\
\hline
\end{tabular}

of bofedales. On the other hand, archaeological surveys of the territory have provided evidence of the temporal depth of settlements and structures associated with these practices. The tensions between Aymara landscape-production practices and the conservation instruments (according to national and international policies) applied in this area are highlighted and discussed, with the aim of contributing to the study of Andean mountain ecosystems in general and of wetlands in particular. The results constitute an invitation to denaturalize Andean landscapes, to stress the role of herders in creating them, and ultimately to recognize traditional ecological knowledge as integral to ecosystem sustainability and territorial justice.

\section{Methodology}

Data was collected through various fieldwork activities conducted during 2011 and 2014-2017. We developed a multi-method approach focused on ethnographic, ethnobotanical and archaeological work within the Aymara community of Mulluri (Figure 1). Through interviews, participant observation and participatory mapping workshops, we aimed to understand local management practices, perceptions and productions of the landscape. We also conducted surveys about traditional livestock management and its relationship with official conservation policies. Aymara community members currently living in the city of Arica also participated. Archaeological surveys were carried out alongside the herding circuits, providing chronological and material data which was complemented by oral histories. We also undertook archival research of preservation plans in official repositories related to the SNASPE of the study area. Further information was collected by the authors during preliminary fieldwork in 2009, and short follow-up field campaigns in the research area during 2018 and 2019.

\section{Denaturalizing the cultural landscapes: Aymara costeo and bofedal management in the Dry Puna}

The Andean Puna is a large mountainous area shared by Peru, Bolivia, Argentina and Chile, comprising different ecozones, with both longitudinal and latitudinal climate variations. From north to south are the Humid Puna (Titicaca Basin), Dry Puna (Desaguadero, Lauca \& Tarapacá), and Salt Puna (Atacama)
(Núñez \& Santoro 1988). Following the altitudinal gradient of the Andes from west to east, the differences are more marked: the Low Puna and High Puna are below and above $4000 \mathrm{~m}$ a.s.l. respectively. Each has its own vegetational floors - Pre-Puneño or desert floor (2600-3300 m a.s.1.), Puneño or Tolar (3300-4000 m a.s.l.), Altoandino or Pajonal (4000-4300 m a.s.l.) and Subnival (ca. 4400-4800 m a.s.l.) (Villagrán et al. 1999). The Puna is under the influence of both the South Pacific High (a subtropical anticyclone) and the rain shadow effect of the Andes, which blocks moist air from the Amazon basin. Both factors produce very dry and stable conditions, with annual precipitation being concentrated over the summer months (December to March) (Garreaud 2009).

Aymara cultural practices associated with livestock and landscape production are seasonal, organized around the cycles dictated by the rainy period and its related pasture growth cycle, which in turn mobilizes the transhumance circuits (Villagrán \& Castro 1997; García et al. 2018). Aymara herders identify three seasons within the annual cycle: jallu pacha, rain time; thaya pacha, cold season or pasture time; and lupi pacha, dry season (Bouysse-Cassagne \& Harris 1987; van Kessel 1992).

Herders and their herds move along different circuits exercising a high level of mobility, interacting with different ecosystems (humid and rain-fed) along the altitudinal gradient, thus providing year-round grazing for livestock throughout the seasons and generating a dispersed settlement pattern. Research has focused on different modalities of transhumance according to the region: in the Humid Puna, mobility is restricted, and herders ascend to the High Puna during the rainy season, where they have small settlements of shelters locally known as chozas, cabañas or musiña (Flores Ochoa 1977; Palacios 1988; Quispe \& Blanco 2018). In the Salt Puna, during the summer rains, agropastoral communities also ascend with their herds to the High Puna, where they have small, temporary settlements known as estancias (Berenguer 2004; Villagrán \& Castro 1997; Göbel 2002).

By contrast, Dry Puna herders have developed a transhumance system, the costeo, with a high degree of mobility. The term comes from the word costa (coast) and refers to the Low Puna, where the herders spend the winter. Costeo involves a movement from east to west of decreasing altitude, from the estancias or main settlements located in the High Puna (Pajonal floor) to the headwaters at the piedmont ravines (e.g., Camar- 
ones, Camiña, Aroma and Tarapacá) located both in the Tolar and Pre-Puneño floors (Villagrán et al. 1999). The Tolar floor, at the core of the Aymara coast, presents the greatest coverage and diversity of species, due to the convergence of moderate altitude and abundant rainfall - both determinants for vegetation growth (Villagrán et al. 1999). In this lower ecozone, herders' paskanas (shelters) are used seasonally by each family unit (Provoste 1976; Gundermann 1988; van Kessel 1992; García 2018). Our archaeological work in Mulluri (García 2018) suggests that some of these have been used continuously since pre-Hispanic times (Figure 2).

Costeo takes place during the cold, dry season (March to September). Its importance to herding lies in the fact that rain-fed pasture continues to grow in the Andean piedmont despite the lack of rain, whereas in the High Puna grazing land is covered by ice and snow (Provoste 1976; Villagrán et al. 1999) - hence the name of the season, tiempo de pasto (pasture time), at the end of which, and once the peatlands are no longer frozen, herders return to the High Puna (García 2018).

The perceptions and imaginaries associated with the Aymara costa refer to a temperate or even hot landscape, because "no bela [hiela] ni neva [nieva]" (it neither freezes nor snows) (male adult, Mulluri 2016) as it does in the cordillera. These perceptions differ significantly from the scientific construction of the same physical landscape. Climatology defines this costa as a marginal high desert climate (BWH) where a cold, dry climate with an absence of surface watercourses predominates, making agriculture impracticable. Herders, on the other hand, associate this landscape with pasture time - considered the best time of year, as it is the time when springs refill, grass grows, and livestock fatten up to survive the dry season beginning in September (García 2018).

Ethnobotanical research, including our recent work at Mulluri, highlights the diversity of costa plants known to herders as forage, which cover almost 50\% of the puna floor or tolar (Villagrán et al. 1999; García et al. 2018). With the seasonal rotation or costeo, livestock fertilizes the soil with manure and consumes or harvests the grasses that have grown thanks to the manure from the previous year. This draws attention to the role of the animals themselves, who, as a herder told us, "return to their guano" each year, thus establishing the seasonal herding patterns and circuits. These patterns simultaneously give the bofedales a chance to descansar (rest); during this season, bofedales are irrigated by the herders (July), preparing them for the ice to melt and the arrival of the herds in September (García 2018; Yager et al. 2019).

The bofedales are a type of high-altitude peatland (between 3200 and $5000 \mathrm{~m}$ a.s.l.), dominated by cushion-like plants (e.g. Oxychloe andina, Distichia muscoides) which form layers of peat (Squeo et al. 2006; Ruthsatz 2012). Herders maintain the bofedales throughout the calendar year, enhancing their adaptation to adverse

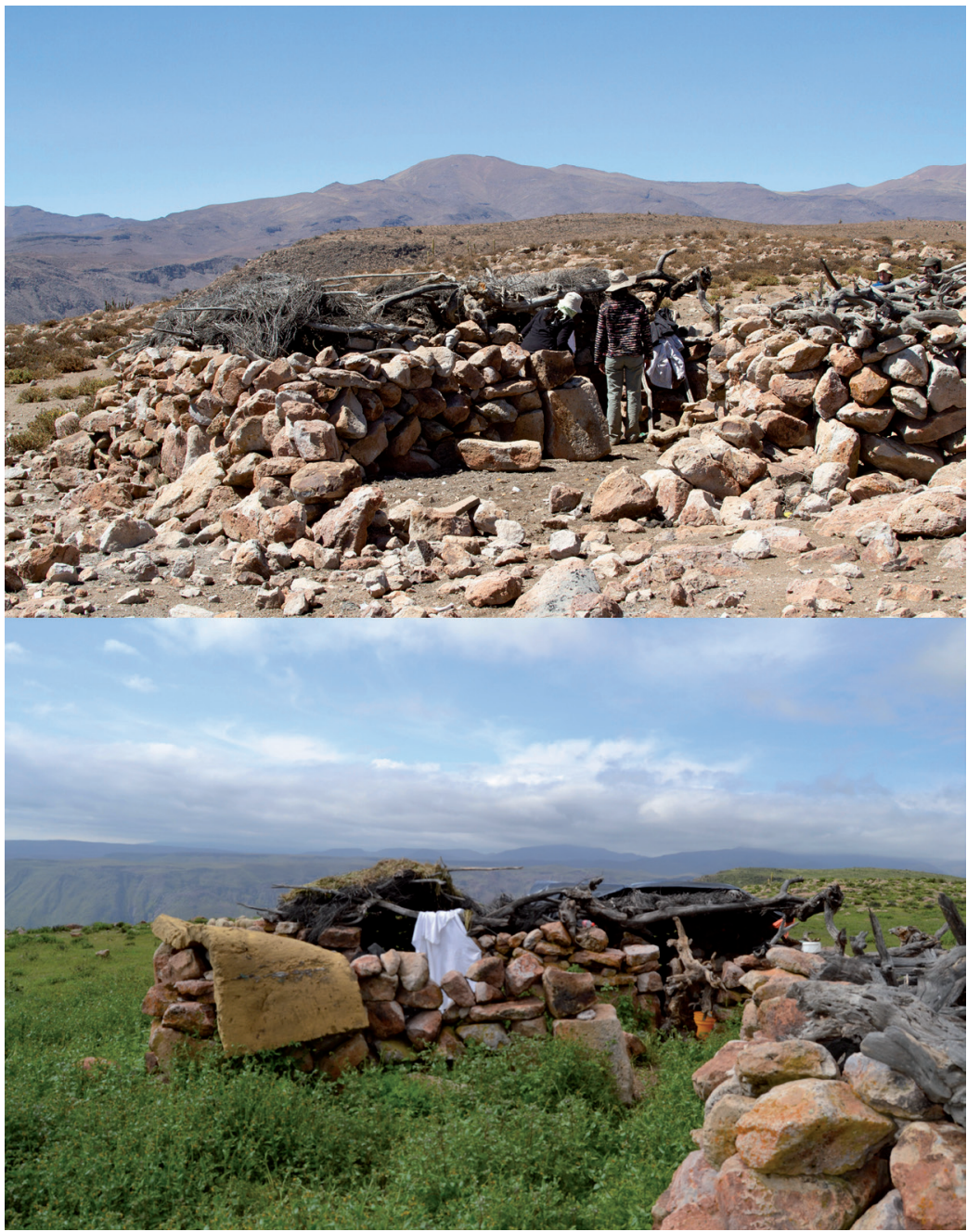

Figure 2 - Paskana in Alto Esquiña, Mulluri territory. Above: dry season, September 2014. (C) P. Méndez-Quirós. Below: Pasture time, March 2017. (C) José Viqa

climatic conditions. Their techniques are diverse, consisting of cleaning, irrigation, manuring and rest periods, which keep the bofedales healthy, reduce erosion, prevent frost, and increase the grazing surface and capacity (Verzijl \& Quispe 2013; Eisenberg 2013; Yager et al. 2019). Intervention occurs to varying degrees, from simple stone dykes and ditches to complex channels, tanks and pipeline networks. Controlled fires are also used to burn colonizer grasses, fertilize the soil, and increase the vigour of new shoots (Figure 3). Mulluri herders say "you have to green the champeal, green the pasture" (García 2018) in reference to bofedal care and its cultural production, also acknowledging the role of animals that graze excess grasses and fertilize the bofedales with their droppings (Yager et al. 2019).

Such practices question the idea that these rain-fed grasslands and bofedales are simple natural pastures, presenting them instead as socio-natural ecosystems (Prieto 2015); these ecosystems sustain herding practices, but their existence also requires the above management practices (Prieto \& Yager 2018; Yager et al. 2019). In view of their network of channels and ir- 

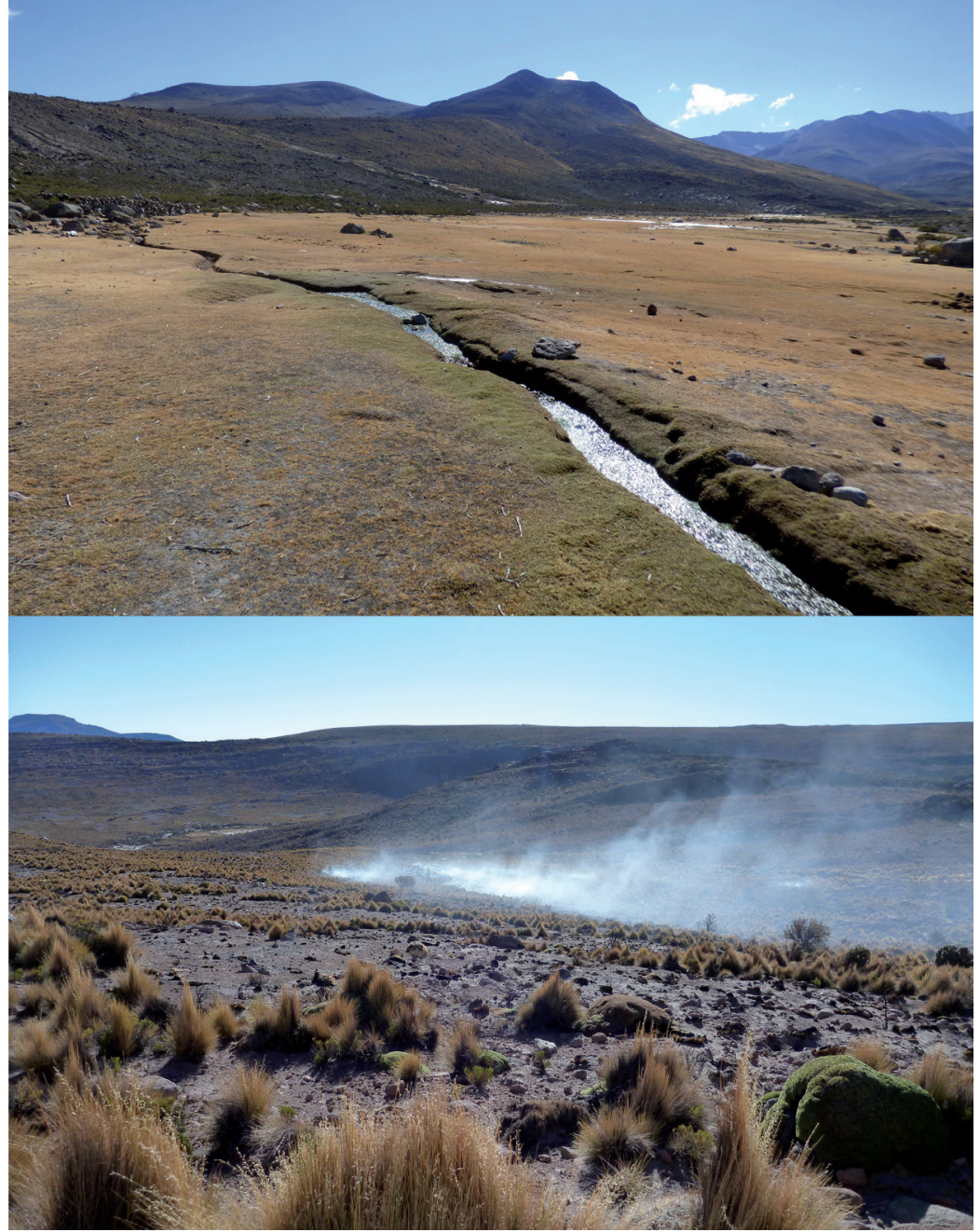

Figure 3 - Landscape management and care practices in Mulluri. Above: bofedal channelling. Below: controlled fires to fertilize grasslands and increase vigour of new shoots. (C) authors

rigation outlets, bofedales can be compared to cultivated land, but they also demonstrate different management practices: the social management of water, canal cleaning and irrigation, while livestock weeds, fertilizes, sows and harvests. This is coupled with a notable number of plants that provide grazing $(62 \%)$ and food for humans $(20 \%)$ in the bofedales (Villagrán et al. 1999; Villagrán \& Castro 2004).

\section{National and international conservation policies in Aymara territory}

In 1965, the Lauca Forestry Reserve (271300 ha) was created with an emphasis on conserving the vicuña (Vicugna vicugna), a wild South American camelid. In 1970, the reserve became the Lauca National Tourism Park, doubling its surface area (520000 ha) and emphasizing tourist activities. In 1983, three important events occurred under the Pinochet dictatorship. First, the park was split into three units: Lauca National Park (137883 ha), Las Vicuñas National Reserve (209131 ha), and Surire Natural Monument
(11298 ha), reversing public ownership of over 161000 ha (D.S. 29 of the Ministry of Agriculture). Protected areas were also declared to be sites of scientific interest for mine exploration (CONAF 2008). Second, the new Mining Code created exploration and extraction concessions in protected areas. Finally, the UNESCO Lauca Biosphere Reserve was also created in 1983 and included the three aforementioned protected areas. The focus of these reserves today is to link research and development associated with the loss of biodiversity, climate change and sustainable development - thus promoting a greater participation of science in policies on the rational use of biodiversity (Borsdorf et al. 2013).

In contradiction to the conservation purpose of the reserves, the State has granted mining concessions to various companies (e.g., Quibórax, formerly Choquelimpie mine) with a significant impact on Puna ecosystems and local communities. Additionally, the diversion of the Lauca River in 1962 toward the Azapa Valley for hydroelectricity and irrigation has affected Aymara water security and ecosystems, and has created geopolitical tensions with Bolivia (Eisenberg 2013). These policies, coupled with urban migration and the subsequent depopulation of indigenous territories, reflect the imaginary vision of this territory as terra nullius, allowing for its control by the state and private capital (Eisenberg 2013; Prieto 2015).

\section{CONAF management plans and Aymara participation}

Until the early $21^{\text {st }}$ century, the local demographic component and ecosystem management practices were not mentioned or considered in CONAF management plans. Only recently has CONAF for the first time considered a participatory management approach involving the local indigenous community (CONAF 2008). The document associated with the Lauca National Park recognizes the high degree of knowledge that Aymara people have developed over time of the diverse characteristics of ecological profiles, with their heterogeneity of climates, altitudes, flora and fauna and use of resources from all these areas (CONAF 2008: 34). It also recognizes that the traditional use and management of Puna resources protected the area from over-exploitation - a balance that was broken with the emergence of individual private property, along with a subdivision of community lands, competition for resources, and income from state-owned property, to name a few (CONAF 2008: 36).

Despite this recognition, CONAF management plans $(1998,2008, \mathrm{n} / \mathrm{d})$ do not confer an active role upon herders in the management of park ecosystems. The documents indicate that the management experts are those who plan and put proposals to the local population or gather the latter's knowledge and then re-express it using technical language. In this way, the herders' role is first relegated and then fur- 
ther reduced to a secondary level. Although there are periodical events to involve local communities, Jofré (2014) states that local residents criticize these for not being consultative or participatory but rather merely informative. Our analysis of CONAF's management plans confirms Jofré's statement: they are predefined and reductive, based on business models and giving no room for discussion with community members.

As part of engaging with the local population in the reserve and involving them in development, the Lauca National Park management plan has proposed the creation of a Cultural Promotion Program. Among its objectives are exchanges of knowledge and experience, a revalorization of living heritage, and an interest in disseminating and enriching the particular local vision of the interaction between humans and nature (CONAF 2008: 74). It also proposes a Comprehensive Training Program, which includes training in environmental education and biodiversity conservation, and instructing local people in data recording and monitoring.

At the same time, development programs focus on tourism as a business opportunity, stimulating competition over cooperation, and are thus in conflict with management plans that respect indigenous people and their practices. CONAF has promoted new values in which economic concerns dominate cultural ones, imposing new ways of life related to market forces and economic rationale (Rivera Andía 2019). Jofré (2014) indicates that there is a negative perception of the programs among the local residents of Guallatire, as the tourism plan would only benefit a few people, increasing inequality within the community. Jofré also describes the confrontational climate and absence of dialogue between the indigenous community and government institutions. Similarly, Eisenberg (2013: 140) notes that the funds that maintain wildlife management programs do not permit any direct benefits to the Aymara people. The park's management plan was a unilateral imposition in which the local Aymara population had little or no imput.CONAF, like mining companies, restricts and has a negative impact on the Aymaras' everyday life (Eisenberg 2013).

Analysis of the CONAF documents shows that the priorities, issues and main concerns expressed by community members at the meetings (e.g., the competition between wild and domestic camelids for bofedal fodder) are ignored. There are also profound differences at an ontological level, where relations between humans and non-humans are defined, redefined and negotiated (see Blaser 2009). On the one hand, locals regard the land as a mother (Pachamama), and their interactions with animals and plants pursue a principle of reciprocity. On the other hand, CONAF promots a hegemonic binary division between nature and culture, the physical and the metaphysical, the material and the spiritual. In the Aymara world, these distinctions do not exist, for everything is interwoven (de la Cadena 2015). For example, the management plan for Las Vicuñas National Reserve aims to promote the participation of Aymara communities in the produc- tive management of the vicuna, attempting to make their management compatible with a scarce resource. This perspective reduces the vicuña to a resource, in circumstances where the Aymara worldview places it in a heterarchical relationship with humans - and even as mediator in the relationship between humans and sacred mountain entities (van Kessel 1998; Cereceda 2010; de la Cadena 2015). It also fails to acknowledge the close emotional bonds of herders with their herds, which they raise as their own (Flores Ochoa 1977). Finally, there is also a lack of understanding of Aymaran ritual technologies (Lansing 1991). These are important both in terms of practical livestock management (e.g., k'illpa, wayno, machaje, etc.) and in terms of the beliefs that they embody. Indeed, these ritual technologies are considered fundamental to livestock raising, and the animals' health, fertility and reproduction (van Kessel 1998; Dransart 2002; Eisenberg 2013).

CONAF presents bofedales as priority areas in management plans. However, no mention is made of the role of herders in the production of these landscapes. Indeed, there is no mention of the herders at all, and the ecosystems are defined as natural grasslands (CONAF 2008: 44), which is coherent with the SNASPE, at the core of which is the concept of Wild. In addition to naturalizing the bofedales, CONAF provides lessons on the best practices for herders. It emphasizes that livestock activities should be sustainable and should consider the capacities of the bofedales, avoiding their over-exploitation by livestock at the expense of wildlife. The canalization of the bofedales is part of the Aymara cultural practice to ensure a dependable water supply for both cold and dry seasons (Eisenberg 2013; Yager et al. 2019). Due to the ecological problems produced by the diversion of the Lauca River, Eisenberg notes that if water diversion and appropriation continue, the bofedales will inevitably dry up, leading to the disappearance of Ilama and alpaca herds and the highland people who depend on them (Eisenberg 2013: 140).

Of the rain-fed grasslands or pastures that grow on hills and pampas, CONAF states that 'these only provide complementary feed (to livestock) due to their low nutritional value' (CONAF 2008: 44). On the contrary, as we have already indicated, these grasslands play a fundamental role in Andean herding, forming a structural part of traditional livestock management, and are not merely supplementary grazing (Gundermann 1988. Based on our work in Mulluri, we would affirm that during pasture time (March-August) livestock feeding is completely dependent on this food source, as it allows the animals to reach their optimal weight to survive the dry season, thereby guaranteeing the economic and social welfare of the community.

Also of relevance are the hunting restrictions, and measures concerning the collection of Chilean flamingo (Phoenicopterus chilensis) and Darwin's rhea (Rhea pennata) eggs, the collection of native plants, and the use of fire, which apply to both visitors to the Reserve and local communities, as reported by local residents 
in Guallatire and Isluga (Dransart 2002; Eisenberg 2013; Jofré 2014). These resources are fundamental to the Aymara's daily diet, construction of dwellings, fuel and medicine, among other uses (cf. Villagrán et al. 1999; Villagrán \& Castro 2004; García et al. 2018). Furthermore, controlling predators and the use of fire are essential to increase grazing capacity. Finally, the local residents of Guallatire report that the authorities who visit the Reserve consider the empty homes to be 'abandoned'. In reality, they are empty because of the high mobility of the herders, the simultaneous maintenance of several dwellings, and the long hours spent in the field each day (Jofré 2014; van Kessel 1992; Garcia 2018). Finally, we have noted how CONAF and technical studies aim to limit burn practices and consider that these have a negative impact on ecosystems (see also Dransart 2002).

\section{Towards greater territorial justice}

Aymara herding practices are rooted in traditional ecological knowledge developed through the cumulative experiences of generations, from the first attempts to domesticate camelids and the development of Andean herding lifeways since circa 2500 BCE. (Capriles \& Tripcevich 2016). These practices have been perfected, and transmitted both orally and through sitespecific tasks over generations (Flores Ochoa 1977; Lane \& Grant 2016). Among other activities, herders practise costeo and care for bofedales. These are based on - and interwoven with - the cycles of nature, not only enhancing the fertility of the herds, but also producing richer ecosystems. Thus, the Puna is the result of collaborative engagement between human and nonhuman agents, within a specific historical context and distinct ontology (de la Cadena 2015; Rivera Andía 2019). In other words, herders have created their environment through a relationship of co-production, rather than settling in - or for - a pre-provided landscape (Prieto \& Yager 2018).

Hegemonic ideas about nature present human action as a destructive force (Dove \& Carpenter 2006), where humans represent a threat to the conservation of nature. In Chile, the entanglement between centralized decision-making processes, the institutional denial of multiple socio-ecological realities, the lack of recognition of indigenous peoples, and the developmentalist conservation and management policies that overlook traditional knowledge have all reproduced dynamics of internal colonialism (Blaser 2009). Similarly, CONAF conservation policies and management plans have disregarded indigenous herding practices, their cultural value, and their material effects on the conservation of Puna ecosystems. These dynamics weaken the autonomy of the local population in managing, caring for - and producing - their own territories (Jofré 2014).

Those who still inhabit these areas and continue herding deal with the experience of living inside pro- tected areas. Here, a colonial legacy intersects with economic and geopolitical interests in fixing boundaries and determining who can gain access to resources, and how they can use them. This scheme is sustained by prioritizing expert knowledge over traditional ecological knowledge, suppressing and erasing other possible worlds (Blaser 2009).

Rather than imposing conservation policies that reify, ignore or minimize indigenous agency, we suggest that traditional ecological knowledge should be considered as part of a larger project for territorial and environmental justice, since it invites us to understand cultural practices as a productive driver of nature (Posey 1985; Fairhead \& Leach 1996). This would necessitate Aymara self-governance over their claimed territories. The active role of Aymara communities in the production of their territory would result in a collective benefit, ensuring the conservation of ecosystems indispensable to the sustainability of mountain environments (Yager et al. 2019; Yepez 2020). Within the current context, however, consultations and participatory opportunities have a token value only and do not lead to any binding decisions. Both nature management and conservation instruments - as well as scientific research agendas - must open up spaces for traditional knowledge in pursuit of a productive dialogue for the co-creation of knowledge that recognizes mutual opportunities and limitations. This should translate into new conservation strategies, policies and knowledge construction which recognize the political role of indigenous communities in managing - and caring for - territory.

\section{Acknowledgments}

We are grateful to the Aymara community of Mulluri and their president, Aracely Mamani, for authorizing us to work in Mulluri territory and to delve into their memories. Funding was provided by the Universidad Católica del Norte Postdoctoral Fund No. 0001, ANID Fondecyt 1201527, ANID Fondecyt 1181829, ANID PAI 79160085, ANID FONDAP 15110006 and ANID PIA SOC180023. We thank G. Sandoval for the map. We also thank the anonymous reviewers that allowed us to improve the text.

\section{References}

Berenguer, J. 2004. Caravanas, interacción y cambio en el desierto de Atacama. Santiago. [In Spanish]

Berkes, F. 1999. Sacred ecology: traditional ecological knowledge and resource management. Philadelphia, PA.

Blaser, M. 2009. The threat of the Yrmo: the political ontology of a sustainable hunting program. American Anthropologist 111(1): 10-20.

Borsdorf, A., M. Mergili \& L. Ortega 2013. La Reserva de la Biósfera Cinturón Andino, Colombia. ¿Una región modelo de estrategias de adaptación al 
cambio climático y el desarrollo regional sustentable? Norte Grande 55: 7-18. [In Spanish]

Bouysse-Cassagne, T. \& O. Harris 1987. Pacha. En torno al pensamiento aymara. In: Bouysee-Cassagne, T., O. Harris, T. Platt \& V. Cereceda (eds.), Tres reflexiones en torno al pensamiento andino. La Paz: Hisbol. [In Spanish]

Capriles, J. \& N. Tripcevich 2016. Advances in the archaeology of Andean pastoralism. In: Capriles, J. \& N. Tripcevich (eds.), The Archaeology of Andean Pastoralism: 1-10. Albuquerque.

Cereceda, V. 2010. Una extensión entre el altiplano y el mar. Relatos míticos chipaya y el norte de Chile. Estudios Atacameños 40: 101-130. [In Spanish]

CONAF n.d. Plan de Manejo Monumento Nacional Salar de Surire. Documento de Trabajo No. 337. CONAF, Chile. Available at: https://www.conaf.cl/ parques-nacionales/normativa-y-reglamento/planesde-manejo-parques-nacionales/ [In Spanish]

CONAF 1998. Plan de Manejo Reserva Nacional Las Vicuñas. Documento de Trabajo No. 296. CONAF, región de Tarapacá, Chile. [In Spanish]

CONAF 2008. Plan de Manejo Parque Nacional Lauca. CONAF, región de Arica y Parinacota. Available at: https://www.conaf.cl/parques-nacionales/ normativa-y-reglamento/planes-de-manejo-parquesnacionales/ [In Spanish]

de la Cadena, M. 2015. Earth Beings. Ecology of practice across Andean worlds. Durham \& London.

Dove, M. \& C. Carpenter 2006. Introduction: Major historical currents in environmental anthropology. In: Dove, M. \& C. Carpenter (eds.), Ecological Anthropology: a Reader: 1-86. Oxford.

Dransart, P. 2002. Earth, water, fleece and fabric. An ethnography and archaeology of Andean camelid herding. London \& New York.

Eisenberg, A. 2013. Aymara indian perspectives on development in the Andes. Tuscaloosa.

Erickson, C.L. 2000. The lake Titicaca basin: a precolumbian built landscape. In: Lentz, D.L. (ed.), Imperfect balance: landscape transformations in the Precolumbian Americas: 311-356. New York.

Fairhead, J. \& M. Leach 1996. Misreading the African landscape society and ecology in a forest-savanna mosaic. Cambridge.

Flores Ochoa, J. 1977. Pastores de Alpacas de los Andes. In: Flores Ochoa, J. (ed.), Pastores de Puna. Uywamichiq punarunakuna: 15-49. Lima. [In Spanish]

García, M. 2018. Otra "Costa” hay en la Puna. Memorias y Materialidad de un Espacio Pastoril en la Sierra de Arica-Tarapacá, Andes del Norte de Chile (ca. 2600-4000 $\mathrm{msnm})$. Unpublished doctoral thesis, Universidad Católica del Norte-Universidad de Tarapacá. [In Spanish]

García, M., V. Castro, E. Belmonte, T. Muñoz, C. Santoro \& J. Echeverría 2018. Etnobotánica y territorio en el pastal de Mulluri (Norte de Chile). Las enseñanzas del pastoreo aymara. Bol Latinoam Caribe Plant Med Aromat 17(5): 522-540. [In Spanish]
Garreaud, R.D. 2009. The Andes climate and weather. Advances in geosciences 22: 3-11.

Göbel, B. 2002. La arquitectura del pastoreo: Uso del espacio y sistema de asentamientos en la Puna de Atacama (Susques). Estudios Atacameños 23: 53-76. [In Spanish]

González, H. 1997. Economía y uso del espacio en la sociedad aymara actual. Actas II Congreso Chileno de Antropología 2: 567-579. Santiago. [In Spanish]

González, H., H. Gundermann \& J. Hidalgo 2014. Comunidad indígena y construcción histórica del espacio entre los aymara del norte de Chile. Chungara 46(2): 233-246. [In Spanish]

Gundermann, H. 1988. Ganadería Aymara, ecología y forraje (Chile). In: Flores Ochoa, J. (ed.), Llamichos y paqocheros. Pastores de llamas y alpacas: 101-112. Cuzco: Editorial Universitaria. [In Spanish]

Hribljan, J.A., D.J. Cooper, J. Sueltenfuss, E.C. Wolf, K.A. Heckman, E.A. Lilleskov \& R.A. Chimner 2015. Carbon storage and long-term rate of accumulation in high-altitude Andean peatlands of Bolivia. Mires and Peat 15: 1-14.

INE 2018. Radiografía de género: pueblos originarios en Chile 2017. Unidad de Estudios y Estadísticas de Género, Instituto Nacional de Estadísticas. [In Spanish]

Jofré, D. 2014. Guallatire: negotiating aymara indigeneity and rights of ownership in the Lauca Biosphere Reserve, northern Chile. Unpublished doctoral thesis, University of Toronto.

Lane, K. \& J. Grant 2016. A question of altitude: exploring the limits of Highland pastoralism in the prehispanic Andes. In: Capriles, J.M. \& N. Tripcevich (eds.), The archaeology of andean pastoralism: 139-157. Albuquerque.

Lansing, J.S. 1991. Priests and programmers: technologies of power in the engineered landscape of Bali. Princeton, N.J.

Núñez, L. \& C. Santoro 1988. Cazadores de la Puna Seca y Salada, norte de Chile. Estudios Atacameños 9: 11-60. [In Spanish]

Palacios, F. 1988. Tecnología de pastoreo. In: Flores Ochoa, J. (ed.), Llamichos y paqocheros. Pastores de llamas y alpacas: 87-100. Cuzco: Centro de Estudios Andinos. [In Spanish]

Posey, D.A. 1985. Indigenous management of tropical forest ecosystems: the case of the Kayapó indians of the Brazilian Amazon. Agroforestry Systems 3: 139-158.

Prieto, M. 2015. Privatizing water in the chilean Andes: the case of Las Vegas de Chiu-Chiu. Mountain Research and Development 35: 220-229.

Prieto, M. \& K. Yager 2018. The invisible irrigation and the social production of bofedales: braiding science with indigenous knowledge. Public Symposium: Extraction, Development \& Indigenous Community Sustainability. Conference, May 11, 2018, The University of Queensland, Queensland.

Provoste, P. 1976. Antecedentes de la estructura socioeconómica de Isluga. Iquique: Centro de Investigaciones Isluga, Universidad del Norte. [In Spanish] 
Quispe, D. \& R. Blanco 2018. Etnoecología de los pastores de puna: un estudio de caso en la comunidad de Sisipa, Pomata. Unpublished undergraduate thesis, Universidad Nacional del Altiplano. [In Spanish]

Rivera Andía, J.J. 2019. Recent methodological approaches in ethnographies of human and non-human Amerindian collectives. Reviews in Anthropology 48(1): 38-56.

Ruthsatz, B. 2012. Vegetación y ecología de los bofedales altoandinos de Bolivia. Phytoecología 42: 133179. [In Spanish]

Squeo, F.A., B.G. Warner, R. Aravena \& D. Espinoza 2006. Bofedales: High altitude peatlands of the Central Andes. Revista Chilena de Historia Natural 79: 245-255.

Van Kessel, J. 1992. Holocausto al progreso. Los aymaras de Tarapacá. La Paz. [In Spanish]

Van Kessel, J. 1998. Tecnología aymara: un enfoque cultural. Cuadernos de Investigación en Cultura y Tecnología Andina 3. [In Spanish]

Veloso, A. \& M. Kalin 1982. Características del medio físico. In: Veloso, A. \& E. Bustos (eds.), El ambiente natural y las poblaciones humanas de los Andes del norte de Chile (Arica, Lat. 181280S), I: 5-12. Montevideo. [In Spanish]

Verzijl, A. \& S.G. Quispe 2013. The system nobody sees: irrigated wetland management and alpaca herding in the Peruvian Andes. Mountain Research and Development 33: 280-293.

Villagrán, C. \& V. Castro 1997. Etnobotánica y manejo ganadero de las vegas, bofedales y quebradas del Loa Superior, Andes de Antofagasta, Segunda Región, Chile. Chungara 29: 275-304. [In Spanish]

Villagrán, C. \& V. Castro 2004. Ciencia indígena de los Andes del norte de Chile. Santiago: Universitaria. [In Spanish]

Villagrán, C., V. Castro, G. Sánchez, F. Hinojosa \& C. Latorre 1999. La Tradición Altiplánica: estudio etnobotánico en los Andes de Iquique, Primera Región, Chile. Chungara 31(1): 81-186. [In Spanish]

Yager, K., C. Valdivia, D. Slayback, E. Jimenez, R.I. Meneses, A. Palabral, M. Bracho, D. Romero, A. Hub- bard, P. Pacheco, A. Calle, H. Alberto, O. Yana, D. Ulloa, G. Zeballos \& A. Romero 2019. Socio-ecological dimensions of Andean pastoral landscape change: bridging traditional ecological knowledge and satellite image analysis in Sajama National Park, Bolivia. Regional Environmental Change 19: 1353-1369.

Yepez, A.M. 2020. Empty spaces that are full of cultural history: an innovative proposal for the management of a protected area of Chimborazo volcano (Ecuador). eco.mont - Journal on protected mountain areas research and management 12(1): 43-49.

\section{Authors}

\section{Magdalena García}

is a Postdoctoral Fellow at the Instituto de Investigaciones Arqueológicas y Museo R.P. Gustavo Le Paige, Universidad Católica del Norte. Her research focuses on the Atacama Desert, and combines paleoethnobotany, the Andean landscape and indigenous archaeology. Calle Tebenquiche s/n, San Pedro de Atacama, Chile. E-mail: manegarciab@yahoo.com.

\section{Manuel Prieto}

is Associate Professor at the Departmento de Ciencias Históricas y Geográficas, Universidad de Tarapacá. His current research focuses on the socio-ecological transformation of high-altitude Andean wetlands in relation to traditional ecological knowledge, extractive industries and climate. Av. 18 de Septiembre 2222, Arica, Chile. E-mail: mprieto@academicos.uta.cl

\section{Fernanda Kalazich}

is a researcher at the Instituto de Investigaciones Arqueológicas y Museo R.P. Gustavo Le Paige, Universidad Católica del Norte. Her research focuses on the Atacama Desert, and combines public archaeology, critical heritage and subaltern studies across different settings and temporalities. Calle Tebenquiche s/n, San Pedro de Atacama, Chile. E-mail: fernanda. kalazich@ucn.cl 